DOI 10.37882/2223-2974.2020.10.39

\title{
ОСНОВАНИЯ И УСЛОВИЯ ДЛЯ ИЗБРАНИЯ МЕР ПРЕСЕЧЕНИЯ В РОССИЙСКОМ УГОЛОВНОМ СУДОПРОИЗВОДСТВЕ
}

\section{GROUNDS AND CONDITIONS FOR CHOOSING PREVENTIVE MEASURES IN RUSSIAN CRIMINAL PROCEEDINGS}

\section{Firsov}

Summary: The article analyzes the grounds and conditions for choosing preventive measures, argued the possibility of using the results of operational-search activities as grounds for choosing preventive measures. In addition, the article substantiates the fact that the investigator, the interrogating officer, and also the court decide on the choice of a preventive measure, having received sufficient data on the alleged, predictive ability of the suspect, the accused to carry out the acts listed in Part 1 of Art. 97 of the Code of Criminal Procedure.

Keywords: preventive measure; suspect; accused; grounds, conditions, evidence, results of operational-search activities.

\section{Фирсов Владимир Григорьевич}

Независимый исследователь firsov_vg65@mail.ru

Аннотация: В статье проведен анализ оснований и условий избрания мер пресечения, аргументирована возможность использования в качестве оснований для избрания мер пресечения результатов оперативно-розыскной деятельности. Кроме того, в статье обосновано то, что следователь, дознаватель, а также суд, принимают решение об избрании меры пресечения, получив достаточные данные о предполагаемой, прогностической возможности подозреваемого, обвиняемого осуществить поступки, перечисленные в ч. 1 ст. 97 УПК РФ.

Ключевые слова: меры пресечения; подозреваемый; обвиняемый; основания, условия, доказательства, результаты оперативно-розыскной деятельности.

являются «основаниями оснований» применения мер пресечения. К ним вряд ли могут быть отнесены фактические данные, полученные оперативным путем, так как они не фигурируют в уголовном деле и их нельзя оценить и проверить[2].

К.Б. Калиновский и А.В. Смирнов исходят из того, что основания избрания мер пресечения - это уголовнопроцессуальные доказательства о конкретных фактах, указывающих на возможные процессуальные нарушения со стороны обвиняемого или подозреваемого, которые закреплены в ст. 97 УПК РФ[3].

По мнению Л.К. Труновой, «основания применения мер уголовно-процессуального пресечения - это обстоятельства, которые связаны исключительно со свойствами подозреваемого или обвиняемого в совершении противоправного деяния, с его моральными, этическими и социально-нравственными мировоззрениями»[4].

Ю.Г. Овчинников считает, под основаниями для избрания меры пресечения следует понимать совокупность сведений, указывающих на:

1. причастность лица к совершению преступления;

2. его возможное противоправное поведение (ст. 97 УПК РФ);

3. обстоятельства, учитываемые при избрании меры пресечения (ст. 99 УПК РФ)[5].

По мнению Е.В. Быковой и Б.А. Цветкова, дознаватель, 
следователь, прокурор и судья должны прогнозировать возможное поведение подозреваемого, обвиняемого не интуитивно, а на основе имеющихся данных, подтвержденных сведениями, собранными и закрепленными в соответствии с требованиями, предъявляемыми к доказательствам (ст.ст. 74 и 75 УПК РФ)[6].

Аналогичную позицию заняла и Л.Б. Алексеева, по мнению которой, для применения любой из мер превентивного принуждения необходимо доказать наличие фактов, свидетельствующих о возможности уклонения лица от выполнения процессуальных обязанностей и стремлении избежать уголовной ответственности[7].

Е.Ю. Жога и В.П. Рукавишников также отметили, что доказательствами, наличие которых позволяет следователю полагать, что обвиняемый может скрыться от органов дознания, предварительного следствия и суда, следует считать фактические данные, полученные из источников, круг которых определен в ч. 2 ст. 74 УПК РФ[8].

П.А. Лупинская отстаивает взгляд, согласно которому любое процессуальное решение может быть принято только на основе установленных фактических данных. «В уголовно-процессуальной деятельности обстоятельства, составляющие фактическое основание решения, устанавливаются путем доказывания - деятельности, состоящей в собирании, проверке и оценке доказательств»[9].

В.А. Михайлов разделяет данные взгляды: «Если у следователя, лица, производящего дознание, прокурора, судей нет уверенности, подкрепленной достоверными доказательствами, что обвиняемый скроется от следствия и суда, либо будет заниматься преступной деятельностью, либо помешает установлению по делу истины или обеспечению исполнения приговора, то применять меры пресечения они не вправе, в таких случаях у обвиняемого отбирается обязательство являться по вызовам и сообщать о перемене места жительства»[10].

Таким образом, в настоящее время в теории господствуют точки зрения, согласно которым, основания для избрания мер пресечения устанавливаются только доказательствами в процессе доказывания. Существует и иная точка зрения, относительно оснований для избрания мер пресечения. В соответствии с ней, в качестве оснований для избрания мер пресечения возможно использовать не только доказательства, но и результаты оперативно-розыскной деятельности[11].

Потребность в использования результатов оперативно-розыскной деятельности при избрании мер пресечения по уголовным делам носит объективный характер. Она обусловлена тем, что получение сведений о предполагаемом, прогнозируемом поведении подозреваемого, обвиняемого в кратчайшие сроки при решении вопроса о необходимости избрания меры пресечения только уголовно-процессуальными средствами и методами в современных условиях часто оказывается просто невозможным.

В пользу допустимости использования результатов ОРД в качестве оснований для избрания мер пресечения свидетельствует ч. 1 ст. 11 Федерального закона «Об оперативно-розыскной деятельности». В соответствии с ней результаты ОРД могут быть использованы для подготовки и осуществления следственных и судебных действий.

Не исключает возможность использования результатов оперативно-розыскной деятельности в качестве основания для избрания меры пресечения и нормативное регулирование данного института. Согласно ч. 1 ст. 108 УПК РФ, судья не может принимать решение на основании данных, не проверенных в ходе судебного заседания, в частности результатов оперативно-розыскной деятельности, представленных в нарушение требований ст. 89 УПК РФ. Из данной нормы следует, что законодатель связывает использование результатов оперативнорозыскной деятельности в качестве оснований для избрания меры пресечения с их проверкой и соблюдением требований ст. 89 УПК РФ. Таким образом, в обоснование решения об избрании меры пресечения могут быть положены лишь такие сведения, полученные оперативным путем, которые содержатся в источниках, допускающих их проверку в соответствии с уголовно-процессуальным законодательством. Использование результатов ОРД в интересах уголовного судопроизводства предполагает представление их в орган дознания, следователю или в суд в соответствии с нормативными документами.

При этом законодатель проявил неточность. Анализ текста ст. 89 УПК РФ показывает, что она не регулирует порядок представления результатов оперативно-розыскной деятельности, а содержит лишь запрет использования в доказывании результатов оперативно-розыскной деятельности, если они не отвечают требованиям, предъявляемым к доказательствам УПК РФ.

Представляется, что устанавливать в процессе доказывания наличие достаточных оснований для возможного осуществления подозреваемым, обвиняемым действий, перечисленных в ч. 1 ст. 97 УПК РФ, логически не правильно и не соответствует целям доказывания. В процессе доказывания устанавливаются обстоятельства произошедшего преступления. Именно с ним связаны обстоятельства, подлежащие доказыванию по уголовному делу (ст. 73 УПК РФ).

При избрании меры пресечения основания связываются не с обстоятельствами, входящими в предмет доказывания по уголовному делу, а с обстоятельствами 
прогнозируемого поведения обвиняемого, подозреваемого, могущими препятствовать производству по уголовному делу.

Установить достоверно в ходе доказывания предполагаемую возможность осуществления подозреваемым, обвиняемым действий, перечисленных в ч. 1 ст. 97 УПК РФ, невозможно, так как может быть получен вывод о том, что подозреваемый, обвиняемый «может» (с большей или меньшей вероятностью) совершить действия, предусмотренные ч. 1 ст. 97 УПК РФ. В процессе доказывания устанавливаются уже произошедшие события, явления и свойства объективной реальности, нашедшие свое отражение в настоящем.

Как отметил В.И. Зажицкий, субъекты доказывания познают обстоятельства преступления, совершившегося в прошлом, поэтому большинство таких обстоятельств устанавливается опосредованным путем, т.е. с помощью уголовно-процессуальных доказательств[12].

При этом необходимо отметить, что сведения, дающие достаточные основания полагать, что подозреваемый, обвиняемый скроется от органов предварительного следствия или суда, может продолжать заниматься преступной деятельностью, угрожать свидетелю, иным участникам уголовного судопроизводства, уничтожить доказательства, либо иным путем воспрепятствовать производству по уголовному делу, не входят в круг обстоятельств, подлежащих доказыванию, предусмотренных ст. 73 УПК РФ. Поэтому точка зрения, согласно которой данные сведения могут быть только доказательствами, не соответствует уголовно-процессуальному закону. Указанные сведения, в том числе и результаты ОРД, должны быть приобщены к материалам уголовного дела. В судебном заседании при рассмотрении ходатайства следователя об избрании меры пресечения подозреваемому, обвиняемому, указанные конкретные, фактические обстоятельства, послужившие основаниями для избрания меры пресечения, должны быть проверены.

С учетом конкретных целей, на достижение которых направлен домашний арест, а также избрания данной меры пресечения в начальный период расследования уголовного дела, после задержания лица, когда сведений, полученных путем производства следственных действий, как правило, крайне мало, представляется правильным и рациональным использование в качестве оснований для избрания данной меры пресечения имеющихся результатов оперативно-розыскной деятельности, представленных в соответствии с требованиями действующих нормативных правовых актов.

Необходимо учитывать, что основаниями для избрания подозреваемому, обвиняемому меры пресечения в виде домашнего ареста являются достаточные данные о том, что он может совершить нежелательные действия, то возможность совершения этих действий носит предположительный, прогностический характер. Эти действия еще не совершены, но могут быть осуществлены.

Существует и иная точка зрения. Так, по мнению ряда авторов, «основанием применения мер пресечения является не субъективное представление о вероятном поведении обвиняемого, а достоверно доказанное его ненадлежащее поведение. Чтобы стать основанием применения уголовно-процессуального принуждения, ненадлежащее поведение субъекта должно выражаться в нарушении процессуальной нормы.»[13]. В.В. Смирнов полагает: «К моменту принятия решения об избрании меры пресечения должна быть установлена совокупность обстоятельств, свидетельствующих о ненадлежащем поведении в процессе расследования. Если в основу об избрании меры пресечения будут положены достоверные фактические данные о ненадлежащем поведении обвиняемого, а не субъективное мнение о его вероятном поведении, то и само решение будет достоверным»[14].

Точка зрения, допускающая возможность применения мер пресечения только после того, как подозреваемый, обвиняемый уже совершил нарушение процессуальной нормы, внутренне противоречива и не соответствует закону. Внутреннее противоречие в данном случае заключается в том, что обвиняемый уже совершил деяние, целью предотвращения совершения которого является применение меры пресечения. Представляется, что данный подход предполагает избрание меры пресечения после совершения обвиняемым тех деяний, целью предотвращения которых и служит избрание меры пресечения, что является не логичным. Бессмысленно избирать и применять меры пресечения после того, как обвиняемый, подозреваемый совершил действия, для предотвращения которых они предназначены.

Так как обстоятельства, указанные в ч. 1 ст. 97 УПК РФ, носят прогностический характер, применение меры пресечения в виде домашнего ареста возможно при вероятности наступления указанных обстоятельств и имеет смысл до того, как он произошли. Однако данное предположение должно базироваться на соответствующих основаниях, то есть следователь, дознаватель, а также суд, получив достаточные данные о предполагаемой, прогностической возможности подозреваемого, обвиняемого осуществить поступки, перечисленные в ч. 1 ст. 97 УПК РФ, принимает решение об избрании меры пресечения.

На практике возникают сложности, связанные с необходимостью представления в суд для решения вопроса 
об избрании меры пресечения сведений, свидетельствующих о совершении лицом преступления.

По данному вопросу существуют две разных точки зрения. И.Н. Кондрат считает, что «законность и обоснованность применения меры пресечения обеспечивается наличием в деле обвинительных доказательств к моменту избрания этой меры пресечения. Поэтому эти доказательства подлежат всесторонней, полной и объективной оценке независимо от того, применяется данная мера к обвиняемому или подозреваемому»[15].

Согласно другой точки зрения, суду следует ограничиться проверкой наличия оснований для избрания мер пресечения, предусмотренных УПК РФ, не проверяя доказательства, подтверждающие обоснованность обвинения в совершении преступления.

В.М. Корнуков полагает, что «предъявление обвинения и наличие достаточных обвинительных доказательств следует рассматривать не как основание для избрания меры пресечения, а как необходимое условие, порождающее право на ее применение и определяющее субъект, к которому эта мера может быть применена»[16].

Ф.М. Кудин исходит из того, что «если признать обвинение (подозрение) основанием меры пресечения, произойдет смешение оснований производства различных процессуальных действий, сотрется четкая грань между привлечением лица в качестве обвиняемого и применением мер пресечения, которые, по общему правилу, хотя и следуют одно за другим, однако по своему характеру и назначению в системе уголовного судопроизводства далеко не равнозначны»[17].

По нашему мнению, сведения об обвинении или подозрении лица, относятся не к основаниям избрания меры пресечения, а к условиям ее избрания.

Данный вывод подтверждается Пленумом Верховного Суда Российской от 10 октября 2003 г. № 5, который отмечал, что «наличие обоснованного подозрения в том, что заключенное под стражу лицо совершило преступление, является необходимым условием для законности ареста... Должны существовать и иные обстоятельства, которые могли бы оправдать изоляцию лица от общества. К таким обстоятельствам, в частности, может относиться возможность того, что подозреваемый, обвиняемый или подсудимый могут продолжить преступную деятельность либо скрыться от предварительного следствия или суда либо сфальсифицировать доказательства по уголовному делу, вступить в сговор со свидетелями. При этом указанные обстоятельства должны быть реальными, обоснованными, то есть подтверждаться достоверными сведениями.».
Под основаниями избрания меры пресечения в виде домашнего ареста следует понимать достаточную совокупность содержащихся в материалах уголовного дела сведений, позволяющих сделать вывод о реальной возможности совершения обвиняемым, подозреваемым действий, указанных в ст. 97 УПК РФ.

Избрание любой меры пресечения, при наличии предусмотренных законом оснований, возможно только при определенных условиях.

Слово «условие» означает «то, что делает возможным что-нибудь другое, что определяет собою что-нибудь другое»[18].

Н.В. Буланова к условиям избрания меры пресечения относит обстоятельства, создающие правовую ситуацию, которая допускает возможность применения меры пресечения. Такими условиями выступают наличие возбужденного уголовного дела и привлечение лица в качестве подозреваемого или обвиняемого[19].

М.В. Смирнов полагает, что основания и условия представляют собой определенные обстоятельства, указанные в законе и имеющие разное правовое поле. Основания призваны побуждать следователя к действию, а условия при этом обеспечивают учет наиболее значимых, с точки зрения законодателя, факторов. Сочетание оснований и условий в нормативно-правовом регулировании деятельности следователя не только направлено на обеспечение обязанностей уголовного преследования, но и является дополнительной гарантией прав и законных интересов лица, вовлекаемого в производстве по уголовному делу[20].

Разделяя мнение указанных авторов, отметим, что под условиями избрания меры пресечения следует понимать установленные уголовно-процессуальным законом обстоятельства, позволяющие избрать меру пресечения.

При этом основное отличие условий от оснований избрания меры пресечения состоит в том, что к условиям относятся процессуальные, правовые обстоятельства, такие как наличие возбужденного уголовного дела, привлечение лица в качестве обвиняемого и т.д., а к основаниям относятся содержащиеся в материалах уголовного дела сведения, позволяющие сделать вывод о том, что подозреваемый, обвиняемый может совершить действия, указанные в ч. 1 ст. 97 УПК РФ.

Таким образом, для избрания меры пресечения необходимо наличие указанных в законе оснований и условий, соблюдение которых обеспечивает реализацию принципа законности, защиту прав подозреваемого, обвиняемого при избрании мер пресечения. 
1. Ушаков Д.Н. Толковый словарь русского языка. М. Альта-Принт, 2005. 1216 с.

2. Петрухин И.Л. // Уголовно-процессуальное право Российской Федерации: учебник. 3-е изд. перераб. и доп. / Отв. ред. И.Л. Петрухин, И.Б. Михайловская. М. Проспект, 2014. 685 с.

3. Смирнов А.В., Калиновский К.Б. Уголовный процесс. Спб, 2005. 697 с.

4. Трунов И.Л., Трунова Л.К. Меры пресечения в уголовном процессе. Спб Издательство «Юридический центр Пресс», 2003. 356 с.

5. Овчинников Ю.Г. Домашний арест как мера пресечения в уголовном процессе : дис. ... канд. юрид. наук. Омск, 2006. 206 с.

6. Быкова Е.В., Цветков Б.А. Основания применения залога в качестве меры пресечения // Прокурорская и следственная практика. 2003. № 3-4. С. 150.

7. Алексеева Л.Б. Принуждение и ответственность в механизме уголовно-процессуального регулирования // Вопросы борьбы с преступностью. Вып. 30. М., 1979. С. 76.

8. Ж Жога Е.Ю., Рукавишников В.П. Цели и основания применения предварительного заключения под стражу // Следователь. 2000. № 7. С. 86-89.

9. Лупинская П.А. Решения в уголовном судопроизводстве. М. 1976. 238 с.

10. Михайлов В.А. Меры пресечения в советском уголовном судопроизводстве. М., 1991. 188 с.

11. Овчинников Ю.Г. Указ. соч. С. 159.; Светочев В.А. Домашний арест как мера пресечения в уголовном процессе Российской Федерации : дис. ... канд. юрид. наук Калининград 2009. С.121.

12. Зажицкий В.И. Доказывание и доказательства по УПК РФ: теоретико-правовой анализ. 2-е изд., доп. Спб. Юридический центр, 2019.528 с.

13. Перетятько Н.М., Рождествина А.А. Актуальные вопросы применения ограничения свободы и домашнего ареста. Практическое пособие. 000 «Изд-во КноРус» М. 2010.96 C.

14. Смирнов В.В. Арест как мера пресечения, применяемая следователем ОВД. Хабаровск, 1987. 96 с.

15. Кондрат И.Н. Обеспечение прав личности в досудебном производстве по уголовным делам: законодательное регулирование и правоприменительная практика: монография. М. Юстицинформ, 2015. 176 с.

16. Корнуков В.М. Меры процессуального принуждения в уголовном судопроизводстве: монография. Саратов. Изд-во Сарат. ун-та, 1978. 136 с.

17. Кудин Ф.М. Принуждение в уголовном судопроизводстве. Красноярск. Изд-во Красноярского ун-та. 1985. 136 с.

18. Ушаков Д.Н. Толковый словарь русского языка. М. Альта-Принт, 2005. 1216 с.

19. Буланова Н.В. Заключение под стражу при предварительном расследовании преступлений: Научно-методическое пособие / Под ред. докт. юрид. наук М.Е. Токаревой. М. Изд-во «Юрлитинформ», 2005. 256 с.

20. Смирнов М.В. Условия применения мер процессуального принуждения на предварительном следствии // Российский следователь. 2003. № 4. С. 23-24.

(с) Фирсов Владимир Григорьевич (firsov_vg65@mail.ru).

Журнал «Современная наука: актуальные проблемы теории и практики» 